\title{
New Methods of Flash Flood Forecasting in the Czech Republic
}

\author{
Lucie Březková1 ${ }^{1}$, Milan Š́lek ${ }^{1}$, Petr Novák ${ }^{2}$, Hana Kyznarováª , and Martin Jonov ${ }^{3}$ \\ ${ }^{1}$ Czech Hydrometeorological Institute, Regional Office Brno, Kroftova 43, \\ 61667 Brno, Czech Republic \\ ${ }^{2}$ Czech Hydrometeorological Institute, Na Šabatce 17, \\ 14306 Prague, Czech Republic \\ ${ }^{3}$ Czech Hydrometeorological Institute, K myslivně 3, \\ 70800 Ostrava, Czech Republic
}

\begin{abstract}
In June/July 2009 the weather in the Czech Republic was influenced by a 12 days lasting baric low located over Mediterranean, which resulted in a sequence of many flash foods. The total damage was estimated to be about 200 mil. EUR and 15 people died. Although the flash flood is considered as hardly predictable phenomena, first efforts in flash floods forecasting have been already done [1]. Some flash floods can be predicted several tens of minutes in advance. Nowadays, new methods of nowcasting are being developed and they promise a new progress in predicting of these events. The paper shows a detail case study of a flash flood - from the point of view of flash flood forecasting. Based on the results, the prediction system consisting of several nowcasting tools (COTREC, CELLTRACK, etc.) combined with the HYDROG rainfallrunoff model will be set up for testing in operation.
\end{abstract}

Keywords: flash flood, hydrological forecast, hydrological model.

\section{Introduction}

Flash floods are usually considered as almost unpredictible phenomena. However, the development of precipitation monitoring, quantitative precipitation estimates and precipitation nowcasting enable the progress in flash flood forecasting as well. Flash floods caused by localized local heavy precipitations are from the point of view of current meteorological and hydrological forecasting rather "small" phenomena. Thus, the precipitation data used for the prediction of flash floods must be of very high temporal and spatial resolution. In spite of these limitation, the rainfall-runoff process can be simulated and the danger of rapid discharge increase predicted with the hydrological model set up on the particular catchment.

The Czech Hydrometeorological Institute (CHMI) is responsible for following tasks:

- Real-time precipitation monitoring - CHMI operates two weather radars, the radar reflectivities are available in 5 minute step [2], the spatial resolution is 1 square kilometer. 
- Quantitative precipitation estimates (QPE) - rainfall intensities derived from radar reflectivities are combined with the precipitation sums obtained by raingauges to get the most accurate precipitation field, which is calculated operationally in 1 hour step [2], [12].

- Quantitative precipitation forecast (QPF) - several methods of precipitation nowcast (i.e. forecasts up to several hours) are calculated operationally in 5 or 10 minute step.

- Flood forecasting service - the discharge forecast is calculated by hydrological models for more than 100 significant river profiles daily, in case of flood emergency several times a day.

The above mentioned tools were used for the first efforts in flash flood forecasting. The case studies of flash floods, which hit Hodonínka river and Sloup creek, proved that some of flash floods can be predicted several dozens of minutes in advance [1].

It is necessary to stress that the flash flood forecasting deals with great uncertainties, those with major influence are mentioned below:

- The uncertainty of QPE - since radar measurement has many problems, the proper adjustment methods are necessary. Without a raingauge station situated inside or nearby the catchment the QPE is accompanied by significant errors.

- The uncertainty of QPF - the precipitation nowcasting methods are based on extrapolation of radar echo, the development of new storm cells (often crucial) is not considered. So the error of the QPF can be really very high.

It is obvious that the deterministic forecast of a flash flood based on one precipitation scenario can give us only very simplified information about the expected development of the flood. Thus the probabilistic aproach which takes into account all available precipitation scenarios is preferred.

In the paper the detail study of a flash flood which hit Luha catchment on $24^{\text {th }}$ June 2009 is presented. The example shows possibilities but also limitations of the flash flood forecasting. Luha is one of the catchments which have been selected for the flash flood forecasting tested in operation in coming convective season.

\section{The Method}

The method is based on detail analysis of the state in the catchment. As mentioned above, the flash floods hit usually small catchments (the size of the analyzed catchment should be less than approx. $100 \mathrm{~km}^{2}$ ). Since the flash floods are very quick the analysis must be performed repeatedly in small time steps (usually 5 or 10 minutes).

The repeated analysis can be described by so called "evaluation circle" (see Fig. 1), which consists of several steps:

1. Inputs. In this step the QPE and QPF data for the particular catchment are computed. The precipitation forecasts are obtained by various nowcasting methods, for Luha flash flood the following methods were considered: 
- COTREC is radar echo extrapolation technique, which uses two consecutive (10-minute or 5-minute step) maximum reflectivity image of Czech Weather Radar Network (CZRAD) for calculation of motion vector fields; the QPFs are being obtained by calculation of the "nowcast" PseudoCAPPI $2 \mathrm{~km}$ reflectivity in the area of CZRAD domain [3].

- COTREC ext is COTREC applied to the CZRAD extended domain that include radar data from neighboring countries [4].

- Celltrack is an algorithm initially used in the CHMI for identification of cells exhibiting high radar reflectivity, and for their tracking and extrapolation. Cells in the Celltrack algorithm are approximately defined as continuous areas of radar reflectivity equal to $44 \mathrm{dBZ}$ or higher. Extrapolation forecast is made using movement vectors defining cell shift between the last two radar measurements. [5].

- Celltrack ext (history). This method is the same as Celltrack mentioned above but the extrapolation forecast is made using movement vectors that are derived by identification of the cell movement from 1 hour history with the weight decreasing for older movement vectors [5].

- INCA cz. INCA is a software package developed by ZAMG, which combines different inputs such as station data, radar information or Numerical Weather Prediction model (NWP) outputs and uses its own algorithms to process the inputs and provide nowcasts and forecasts of various meteorological quantities; for more detail description see [6]. In this case no NWP data were used since the maximum forecast time was 3 hours.

- INCA ext is the same method as INCA cz, but incorporating also measurement of Polish weather radars.

- COSMO1 The COSMO NWP model [7], version 4.11, with a horizontal resolution of $2.8 \mathrm{~km}$, is applied, and radar reflectivity data are assimilated using a water vapour correction method. The assimilation uses observed radar reflectivity and extrapolated radar reflectivity. The extrapolation is performed by the COTREC method, the length of the extrapolation is 1 hour [8]. COSMO1 utilized the standard one-moment microphysics, a Lin-Farley-Orville type [9], which considers five classes of hydrometeors (rain water, cloud water, snow, ice, and graupel).

- COSMO2 uses two-moment microphysics developed by Seifert and Beheng [10], in this case the set of hydrometeors is complemented by hail.

- Persistence repeats the precipitation intensity derived from the last available radar measurement for the following hour. This procedure can simulate the backbuilding of the storm cells or the quasistationarity of the precipitation system.

As the "bottom" level of the precipitation forecast also the variant "no precipitation forecast" were taken into account. The simulation of discharge forecast based only on measured precipitation input data (assuming that no other precipitation will occur in the catchment) shows the probable minimum discharge increase that can be expected. 
2. Hydrological simulations. Rainfall-runoff simulations are based on all available precipitation scenarios. Thus we obtain the set of various discharge scenarios, which is evaluated in the form of peak discharge exceedance curve.

3. Decision point. The probability of exceedance of the limit water level is the final output of the hydrological simulation. The forecaster must decide whether he/she should issue a warning to the threatened areas. The rule for this decision-making is a subject of a long time testing, because due to the high uncertainty of the whole process there can be a great amount of the false alarms.

4. Proceeding to the next time step.

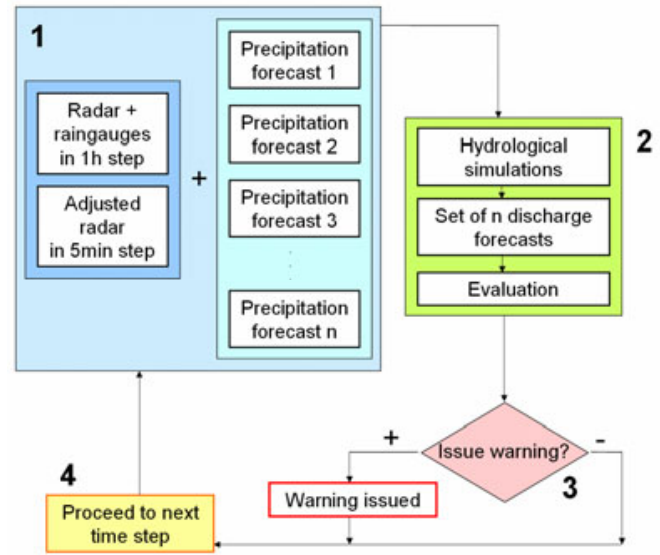

Fig. 1. Evaluation circle - the principle of flash flood forecasting. 1) Preparation of precipitation inputs 2) Hydrological simulations based on various precipitation forecasts (nowcasts). 3) Final decision whether to issue warning 4) Proceeding to the next time step. The evaluation circle should be run in 5 or 10 minute step for every catchment.

\section{Results and Dicussion}

On $24^{\text {th }}$ June 2009 the Luha river catchments was hit by extreme flash flood, the peak discharge exceeded 100 year return time period. The radar based QPEs were strongly affected by attenuation. The Polish radars viewing the squall line from north showed remarkably better performance, probably due to less pronounced attenuation.

Following the process described as "evaluation circle" the simulation of the flood development in $5 \mathrm{~min}$ step has been done. The discharge forecasts were calculated with the use of HYDROG rainfall-runoff model [11]. The discharge in of Jeseník nad Odrou river station was calculated. The particular emphasis was put on the simulation of real operation, that means - the real data availability in the particular time were considered. The examples of the discharge simulations are given on Fig. 2. For every term of the forecast the peak discharge exceedance curves were calculated (see example on Fig. 2). The probability of the discharge exceeding the limits according to the forecast time is given on Fig. 3 and Fig. 4. 

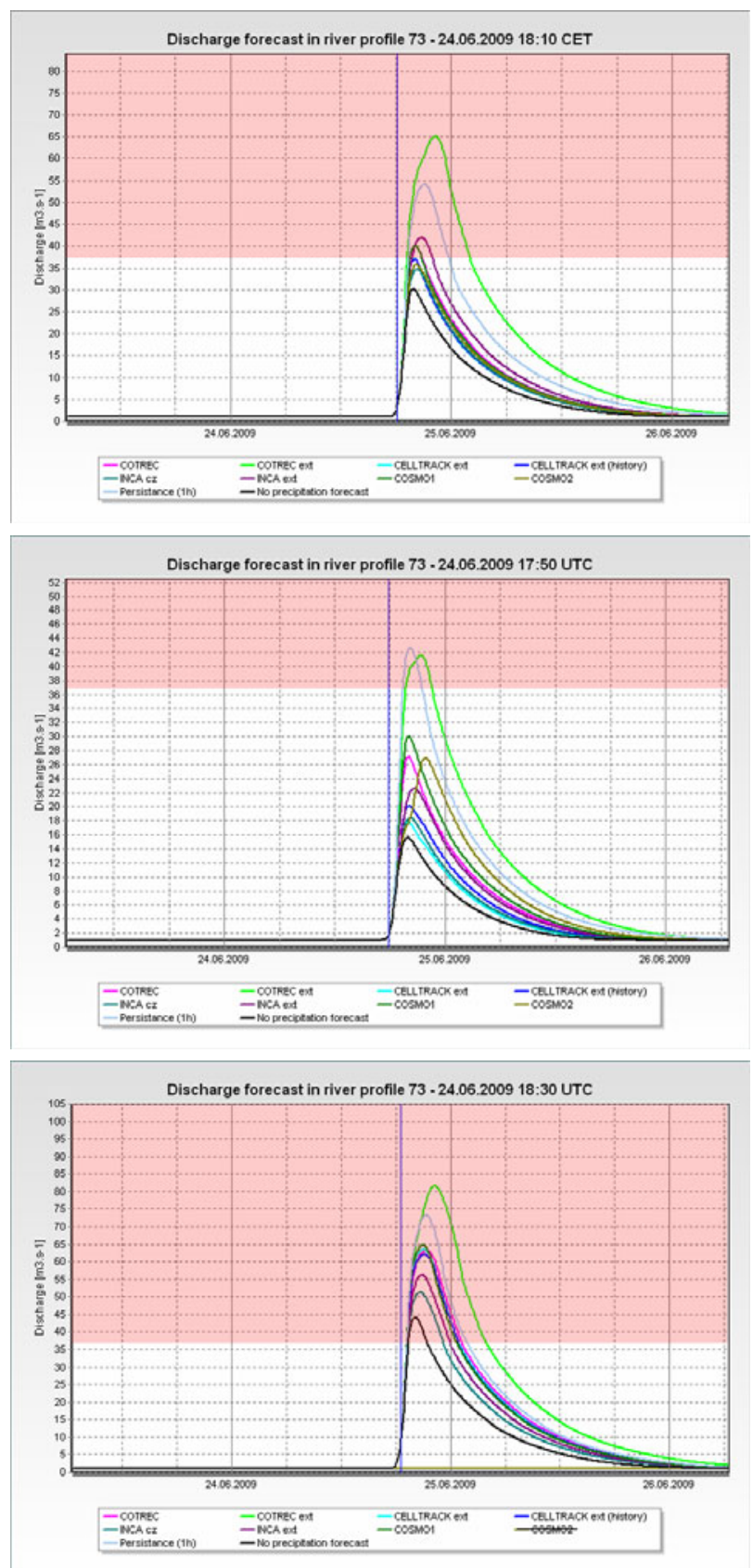

Fig. 2. The simulation of operative discharge forecast at 17:50, 18:10 and 18:30 UTC in the Jeseník nad Odrou river profile according to the various precipitation inputs. The red colour depicts the limit discharge. 

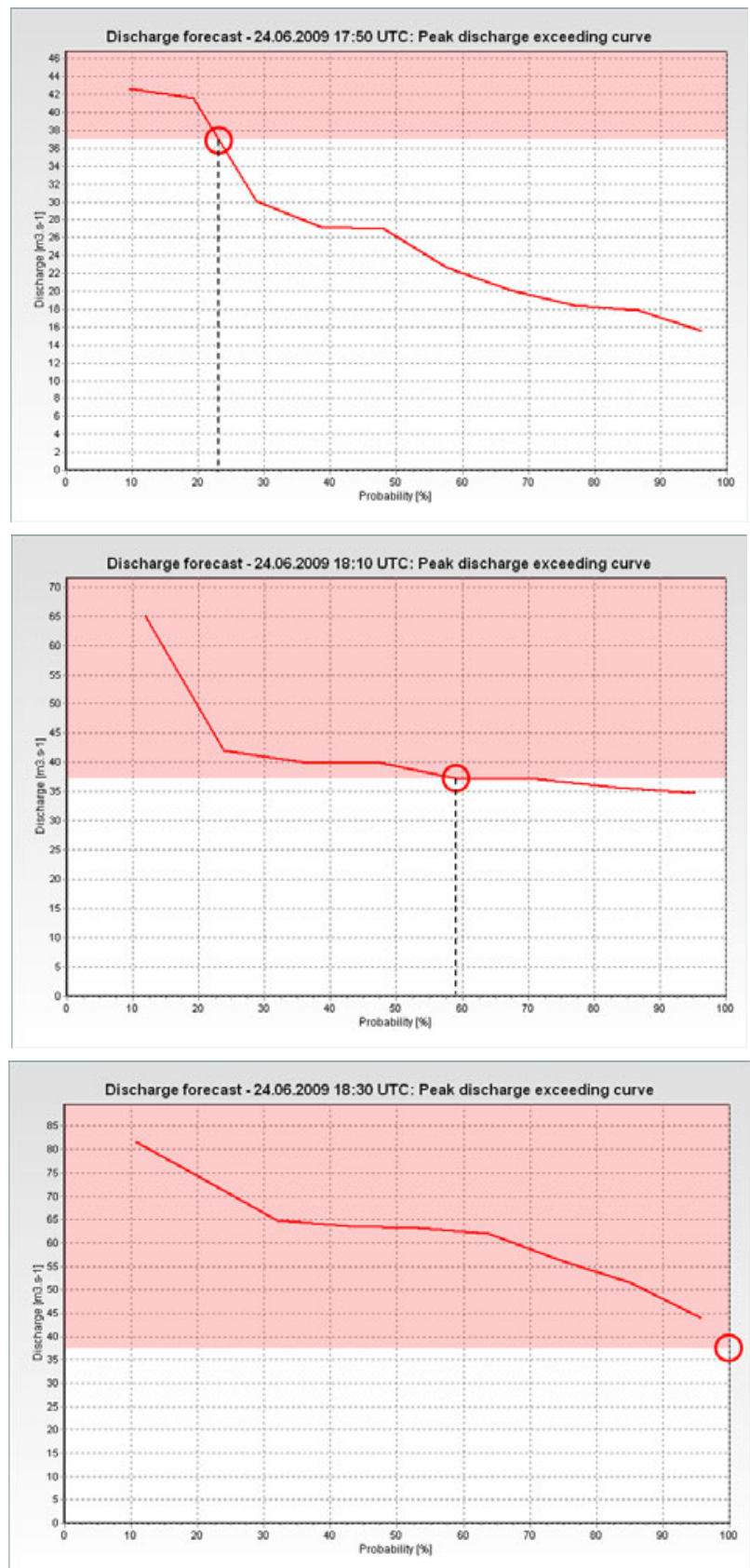

Fig. 3. The simulation of operative discharge forecast at 17:50, 18:10 and 18:30 UTC in the Jeseník nad Odrou river profile - peak discharge exceedance curves. The red colour depicts the flood discharge limit; the probability of the exceedance of the limit is signed by the circle. 


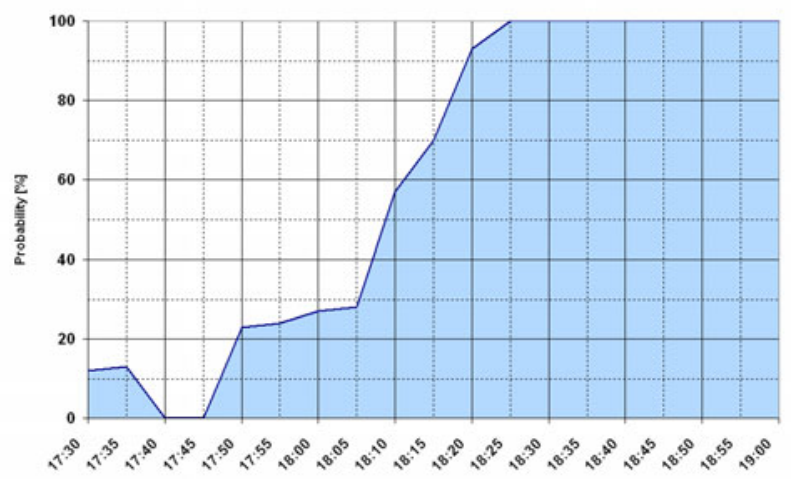

Fig. 4. The estimated probability of flood limit discharge exceedance in the Jeseník nad Odrou river profile in the Luha catchment. As the time proceeds the probability increases and reaches 100 procent.

It is obvious that the probability of the limit discharge exceedance increased in time and reached $100 \%$ level 30 minutes in advance. Such a case can be considered as a reasonably well predicted flash flood and the main success was probably caused by the Bělotín raingauge station which is situated near the Luha catchment. The data from this station improved main precipitation inputs (QPE and also QPF), thus improved also the discharge forecast.

\section{Conclusion}

Some of flash floods can be predicted several dozens of minutes in advance but there is no guarantee that it applies for all events. Our study has confirmed that although the weather radars provide very useful information, their measurements must be corrected by telemetric raingauges, the location of which (according to the flood location) play often crucial role.

However, the system may also produced a lot of false alarms because it has been tested only on cases that resulted in real flash flood; therefore more extensive testing is being planned for the summer season of the year 2011.

Acknowledgments. The work was supported by Central Europe Programme, INCA-CE project (cofinanced by European Regional Developement Fund) and the Czech Republic Ministry of Education, Youth and Sport, project ME09033.

\section{References}

1. Šálek, M., Březková, L., Novák, P.: The use of radar in hydrological modelling in the Czech Republic - case studies of flash floods. NHESS 6, 229-236 (2006)

2. Šálek, M., Novák, P., Seo, D.-J.: Operational application of combined radar and raingauges precipitation estimation at the CHMI. In: ERAD 2004 Proceedings. ERAD publication series, vol. 2, pp. 16-20 (2004) 
3. Novák, P.: The Czech Hydrometeorological Institute's Severe Storm Nowcasting System. Atmospheric Research 83, 450-457 (2007)

4. Novák, P., Frolík, P., Březková, L., Janál, P.: Improvements of Czech Precipitation Nowcasting System. In: ERAD 2010, Sibiu, September 6-10 (2010)

5. Kyznarová, H., Novák, P.: CELLTRACK - Convective Cell Tracking Algorithm and Its Use for Deriving of Life Cycle Characteristics. Atmospheric Research 93, 317-327 (2009)

6. Haiden, T., Kann, A., Wittmann, C., Pistotnik, G., Bica, B., Gruber, C.: The Integrated Nowcasting through Comprehensive Analysis (INCA) system and its validation over the Eastern Alpine region. Wea. Forecasting 26 (2011)

7. Doms, G., Schattler, U.: A Description of the Nonhydrostatic Regional Model LM. Deutscher Wetterdienst (2002)

8. Sokol, Z.: Assimilation of extrapolated radar reflectivity into a NWP model and its impact on a precipitation forecast at high resolution. Atmos. Res, (2011), doi:10.1016/j.atmosres.2010.09.008.

9. Lin, Y.L., Farley, R.D., Orville, H.D.: Bulk parameterization of the snow field in a cloud model. J. Clim. Appl. Meteorol. 22, 1065-1092 (1983)

10. Noppel, H., Blahak, U., Seifert, A., Beheng, K.D.: Simulations of a hailstorm and the impact of $\mathrm{CCN}$ using an advanced two-moment cloud microphysical scheme. Atmos. Res. 96, 286-301 (2010)

11. Starý, M., Tureček, B.: Operative control and prediction of floods in the River Odra basin. In: Flood Issues in Contemporary Water Management. NATO Science Series, 2. Environmental Security, vol. 71, pp. s.229-s.236. Kluwer Academic Publishers, Dordrecht (2000) ISBN 0-7923-6452-X

12. Šálek, M.: Operational application of the precipitation estimate by radar and raingauges using local bias correction and regression kriging. In: ERAD, Proceedings. National Meteorological Administration of Romania, Sibiu (2010) 